\title{
Determinants of intention to use e-wallet using TRAM model
}

\author{
Maulidyati Aisyah*, Ivana Mutia Eszi \\ Department of Accounting, Universitas Islam Indonesia, Yogyakarta, Indonesia \\ Corresponding author email: maulidyati@uii.ac.id
}

A RTICLE INFO

Article history:

Available online

Keywords:

E-wallet, technology readiness, optimism, innovativeness,

discomfort, insecurity

DOI:

https://doi.org/10.20885/jaai.vol24.i $\underline{\text { ss2.art10 }}$

\section{A B S T R A C T}

Financial technology also known as Fintech is the result of a combination of financial services and technology. This changes conventional business models to modern ones. One of the Fintech examples in payment category is digital wallet (e-wallet). The purpose of this study is to determine the effects of optimism, innovativeness, discomfort, and insecurity on the perceived ease of use which influence the intention to use e-wallet. The online questionnaire was used to collect the primary data. The respondents in this study were 127 university students in Yogyakarta Province. The data analysis technique used was SEM (Structural Equation Model). The results of this study indicate that optimism and innovativeness have significant effects on perceived ease of use, and perceived ease of use has a significant effect on intention to use e-wallet. Meanwhile, discomfort and insecurity have no effects on perceived ease of use. Meanwhile, the intervening variable, namely perceived ease of use, functions partially.

\section{Introduction}

Currently, one of the internet uses for transaction is marked by the existence of financial technology (fintech). Fintech makes community activities in transactions more practical and effective and helps people gain access to financial products and increase knowledge related to finance. According to Bank Indonesia, fintech is the result of a combination of financial services and technology, which in turn can change the business model from conventional to modern. With the existence of Fintech, people can access financial products, make transactions, and increase financial literacy more easily (Finansialku.com, 2017). Fintech in the payment category is divided into two types, namely payment gateway and digital wallet (e-wallet). E-wallet users can store their money on the app and use it for transactions both online and offline. Digital wallet is growing rapidly in today's society because it is more comfortable and practical. The users do not need to carry physical money and the money can be saved in several practical ways. Also, it speeds up the transaction times. Some digital wallets that are widely used in Indonesia are Go-Pay, OVO, T-Cash, and Dana. The fintech industry in Indonesia is currently dominated by local e-wallets.

Having optimistic and innovative attitude and thinking is very necessary in today's modern era, especially for young people. The convenience in technology can increase an innovative attitude in a person to become a pioneer in using the technology. The research conducted by Martens et al. (2017) and Khadka and Kohsuwan (2018) show that innovativeness has an effect on perceived ease of use, but optimism has no effect on perceived ease of use. Furthermore, in Simiyu and Kohsuwa (2019) research, the results show that optimism and innovativeness have no effect on perceived ease of use, which is in contrast to the research by Shin and Lee (2014) which shows that optimism and innovativeness affect the perceived ease of use.

Beside the usefulness and ease, there are, of course, risks and weaknesses in using e-wallets. The users must be prepared to face the risks and weaknesses that can make the users feel uncomfortable and insecure. The risk of cybercrime lurks the use of e-wallets that can cause loss of money or balance contained in e-wallet applications (Cermati.com, 2017). The feeling of insecurity arises because in an online transaction a user does not know whether or not the other party in the transaction has good intention. Bad intentions such as fraud and account hacking may occur, so users must be more careful and increase vigilance in make transactions online. In addition, the use of e-wallets can also make users feel uncomfortable because if the e-wallet facilities are not properly regulated, it can lead to budget leakages for the electronic money users. Users will tend to be more wasteful, and the payments that are effortless make people less careful in spending their electronic money (PRIMA, 2020). Therefore, users need to manage their budgets properly in using e-wallets. The existence of transaction fees in cashless transaction systems can also cause users to feel uncomfortable in using e-wallets. 
Many forms of analysis models can be adopted or used to determine and measure the success rate of information technology implementation. This study used Technology Readiness and Acceptance Model (TRAM) model which was first developed by Lin et al. (2005). TRAM is an integration between Technology Acceptance Model and Technology Readiness Index. During its development, there were modifications toward TRAM model as in the research of Shin and Lee (2014). In their study, the results showed that Technology Readiness Index only affected perceived ease of use variable, while perceived of usefulness variable was influenced by the characteristics of technology.

The research conducted by Martens et al. (2017) showed that in South Africa, discomfort and insecurity had effects on perceived ease of use. Furthermore, from the results of the study conducted by Martens et al. (2017) and the research by Khadka and Kohsuwan (2018), discomfort and insecurity had no effects on perceived ease of use. This is different from the research by Shin and Lee (2014) which showed that discomfort and insecurity had negative effects on perceived ease of use. Judging from the differences in the results of the above research, it can be concluded that users view the insecurity and inconvenience of digital payments differently. The research that discusses the relationships between perceived ease of use and interest in using digital payments includes those of Liu et al. (2019) and Sitinjak (2019). These studies show that the perceived ease of use has a significant effect on the intention to use digital payments, and it can be concluded that changes in the level of perceived ease of use can affect the interest in use because if technology is complicated to use, the society will take longer time to learn and operate it. This is inversely proportional to the purpose of technology which is to facilitate us as to reduce interest in using it. In contrast to the research by Humbani and Wiese (2019), Martens et al. (2017) and Shin and Lee (2014) show that perceived ease of use has no significant effect on continuing intention to use digital payments.

Based on the above explanation, this study analyzes the indicators that affect the intention to use e-wallets with perceived ease of use as an intervening variable. The model used was a modified TRAM as in the research of Shin and Lee (2014) so that it is expected to enrich the results of the study, especially in the field of digital payment.

\section{Literature Review}

\section{Technology Readiness Index (TRI)}

Parasuraman (2000) introduced the Technology Readiness Index (TRI). TRI model refers to a person's tendency to support and use new technology to achieve his goals in daily life and at work. The model results from the perceptions that support and inhibit mentality that further collectively determine a person's tendency to use new technology. Furthermore, Pasuraman stated that in TRI there were four basic components, namely optimism, innovativeness, discomfort, and insecurity. Optimism and innovativeness are the driving components (positive) in TRI, while discomfort and insecurity are the inhibiting components (negative). During the model development, Parasuraman and Colby (2014) improved the initial TRI model known as TRI 1.0 with 36 indicators to TRI 2.0 with 16 indicators.

\section{Technology Readiness and Acceptance Model (TRAM)}

TRAM is the result of integration between TAM and TRI models first introduced by Lin et al. (2005). Technology Acceptance Model (TAM) was introduced by Davis in 1986. TAM is an adaptation of TRA which is specially designed to model user acceptance of the system (Davis et al., 1989). TAM uses two specific propositions, namely perceived ease of use and perceived usefulness. Perceived of use is the user's perception on the amount of effort required to use the system, and perceived usefulness is the user's perception on the level of system use which can improve the user performance capabilities (Venkatesh \& Davis, 1996). The two perceived variables can determine attitudes toward use (attitude toward behavior), which then can influence the intention to use technology (behavioral intention) (Davis et al., 1989). However, in the last version of TAM, the attitude variable towards the use of technology was omitted because the perceived usefulness had a strong influence on the intention to use technology, while the effect of perceived usefulness on the attitude variable towards the use of technology was classified as weak. This is because when a technology provides usefulness, people will still intend to use this technology even though they do not have a positive attitude towards the technology (Sitinjak, 2019).

TRAM combines the general dimensions of TRI with the specific dimensions of TAM system to explain how individual readiness can affect individual interaction, experience, and use of new technology (Khadka \& Kohsuwan, 2018). The model in this study combines TRI dimensions consisting of optimism, innovativeness, discomfort, and insecurity with TAM variables which consist of perceived usefulness, perceived ease of use, and intention to use.

\section{Financial Technology}

Financial technology (fintech) emerges by describing the challenges for financial sector in the presence of faster, cheaper, people-centered financial services. According to Purba et al. (2019), fintech is the combination of financial 
services and technology that turns conventional business models, which originally conducted face-to-face payments and carried a certain amount of cash, into modern ones, which can now make remote transactions by payments that can be made in just seconds. Similarly, according to Bank Indonesia, fintech is the combination of financial services and technology, which in turn can change the business model from conventional to modern.

According to Bank Indonesia, fintech has four categories, namely peer to peer lending and crowdfunding, market aggregator, risk management and investment, and payment, clearing, and settlement. The payment category is divided into two types, namely payment gateway and digital wallet (e-wallet). E-wallet users can store their money on the application and use it for transactions both online and offline. Based on the data from Bank Indonesia (2020), there are already 42 e-wallets that are officially licensed. Fintech industry in Indonesia is currently dominated by local e-wallets. The development of digital wallet applications in Indonesia has also increased by 50 percent from 2017 to mid-2019. Digital wallets are growing rapidly in today's society.

\section{Optimism}

According to Parasuraman (2000) and Khadka and Kohsuwan (2018), optimism is a positive view on technology and the belief that technology can provide increased control, flexibility, and efficiency in users' lives. When a technology can provide great convenience and benefits for human life, the users will, of course, feel optimistic about technology, so that it can bring up a positive view on technology and arouse the intention to use it. Optimism reflects a positive view that the use of technology can increase control and efficiency with an optimistic orientation of adopting new technology by openly paying attention especially to its positive aspects in human life (Parasuraman, 2000).

\section{Innovativeness}

Innovativeness is a tendency to become a technology pioneer and thought leader (Khadka \& Kohsuwan, 2018; Parasuraman, 2000). The point is that this variable becomes an indicator in TRI model that provides positive confidence as well as optimism, so that users are motivated by the presence of technology. Innovativeness is one of the positive indicators in TRI which refers to the level at which a person is interested in experimenting with technology and becomes a pioneer in trying the latest technology-based products or services (Aisyah et al., 2014).

\section{Insecurity}

Insecurity indicator in TRI refers to a sense of distrust in technology-based transactions and doubts against the workability of the technology (Martens et al., 2017; Parasuraman, 2000). When users feel insecure about the technology, users are less likely to try and find out more about the latest technology and will avoid using the technology, except when they are under compulsion. The existence of this attitude in an individual can hinder the use of technology.

\section{Discomfort}

According to Martens et al. (2017) and Parasuraman (2000), discomfort is a perceived lack of control over technology and a feeling of being overwhelmed by it. Discomfort indicator shows a feeling of lack of mastery and insecurity in using the latest technology, which causes discomfort in using it. Users who feel discomfort tend to need assistance in operating it or prefer simpler technology. This discomfort creates a feeling of pessimism and non-innovation in a person, so new technology is considered complex and creates the perception that technology will not be easy enough to use.

\section{Perceived Ease of Use}

Perceived ease of use is the user's perception on the amount of effort required to use the system or technology (Liu et al., 2019; Venkatesh \& Davis, 1996). Perceived ease of use indicates an individual belief that using an information technology system will not be a hassle and does not require a lot of effort to use it. When someone feels confident that technology can be used easily or requires a little effort, it will increase one's intention to use the technology Sitinjak (2019).

\section{Intention to Use E-Wallet}

Intention to use e-wallets is an attitude that can be categorized into behavioral intention variable in Technology Acceptance Model (TAM) theory. This is because someone's intention to use e-wallet is the behavior that is shown and obtained after being influenced by perceived usefulness and perceived ease of use from using new technology. Behavioral intention is a behavioral tendency to apply a technology (Davis et al., 1989; Sitinjak, 2019). 
Based on the research conducted by Khadka and Kohsuwan (2018) and Martens et al. (2017), innovativeness affects perceived ease of use, and optimism affects perceived benefits. However, innovativeness has no effect on perceived benefits, and optimism has no effect on perceived ease of use. Furthermore, in Simiyu and Kohsuwa's research (2019), the results show that optimism and innovativeness have no effects on perceived benefits and perceived ease of use. Those studies contradict the research by Shin and Lee (2014) which shows that optimism and innovativeness affect perceived ease of use. The study indicates that innovativeness variable has no effect on perceived benefit variable. Therefore, in this study, perceived benefit as the intervening variable between the independent variable and the dependent variable was removed.

There are several studies on digital payment that used TRAM model. Table 1 is the summary of the results of previous research.

Table 1. Results of previous studies

\begin{tabular}{|c|c|c|c|}
\hline Variable TRI & $\begin{array}{l}\text { The TAM } \\
\text { variable }\end{array}$ & Result & References \\
\hline \multirow[t]{4}{*}{ Optimism } & \multirow[t]{2}{*}{ Ease of use } & significant & Shin and Lee (2014) \\
\hline & & insignificant & $\begin{array}{l}\text { Khadka and Kohsuwan (2018), Martens et al. (2017). and Simiyu \& } \\
\text { Kohsuwa, (2019) }\end{array}$ \\
\hline & \multirow[t]{2}{*}{ Usefulness } & significant & Khadka and Kohsuwan (2018) and Martens et al. (2017) \\
\hline & & insignificant & Simiyu and Kohsuwa (2019) \\
\hline \multirow[t]{4}{*}{ Innovativeness } & \multirow[t]{2}{*}{ Ease of use } & significant & Martens et al. (2017), Shin and Lee (2014) \\
\hline & & insignificant & Simiyu and Kohsuwa (2019) \\
\hline & \multirow[t]{2}{*}{ Usefulness } & significant & Simiyu and Kohsuwa (2019) \\
\hline & & insignificant & Khadka and Kohsuwan (2018) and Martens et al. (2017) \\
\hline \multirow[t]{4}{*}{ Discomfort } & \multirow[t]{2}{*}{ Ease of use } & significant & $\begin{array}{l}\text { Martens et al. (2017), Shin and Lee (2014) and Simiyu and Kohsuwa } \\
\text { (2019) }\end{array}$ \\
\hline & & insignificant & Khadka and Kohsuwan (2018) and Martens et al. (2017) \\
\hline & \multirow[t]{2}{*}{ Usefulness } & significant & $\begin{array}{l}\text { Khadka and Kohsuwan (2018), Martens et al. (2017). and Simiyu \& } \\
\text { Kohsuwa, 2019) }\end{array}$ \\
\hline & & insignificant & - \\
\hline \multirow[t]{4}{*}{ Insecurity } & Ease of use & significant & $\begin{array}{l}\text { Khadka and Kohsuwan (2018), Martens et al. (2017). Simiyu \& Kohsuwa, } \\
\text { 2019), and Shin and Lee (2014) }\end{array}$ \\
\hline & \multirow{3}{*}{ Usefulness } & insignificant & Khadka and Kohsuwan (2018) and Martens et al. (2017) \\
\hline & & significant & Martens et al. (2017), Simiyu and Kohsuwa (2019) \\
\hline & & insignificant & Khadka and Kohsuwan (2018) and Martens et al. (2017) \\
\hline
\end{tabular}

\section{Effect of Optimism on Perceived Ease of Use}

There are four dimensions in TRI, one of which is optimism. Optimism reflects a positive view that the use of technology can increase control and efficiency with an optimistic orientation of adopting new technology openly and paying attention especially to its positive aspects in human life (Parasuraman \& Colby, 2014). Based on the research conducted by Khadka and Kohsuwan (2018), Martens et al. (2017). and Simiyu \& Kohsuwa, 2019), optimism had no positive effect on perceived ease of use. In contrast, the research by Shin and Lee (2014) showed that optimism had a positive effect on perceived ease of use. Based on the differences among the aforementioned researchers, this research tries to re-test this construct by formulating the hypothesis as follows. H1: Optimism has a positive effect on perceptions of ease of use.

\section{The Influence of innovativeness on Perceived Ease of Use}

Innovativeness is one of the positive dimensions in TRI which refers to the degree to which a person is interested in experimenting with technology and becomes a pioneer in trying the latest technology-based products or services (Aisyah et al., 2014). Based on the research conducted by Khadka and Kohsuwan (2018), Martens et al. (2017), and Shin and Lee (2014), innovativeness has a positive effect on perceived ease of use. In contrast, Simiyu and Kohsuwa (2019) study results show that innovativeness does not have a positive effect on perceived ease of use. Based on the differences in those studies, the researcher tried to re-test this construct by formulating the hypothesis below.

$\mathrm{H} 2$ : Innovativeness has a positive effect on perceptions of ease of use.

\section{Effect of Discomfort on Perceived Ease of Use}

Another negative dimension in TRI is discomfort which reflects the user's perception that he is overloaded with and lacks control over the technology. Based on the research conducted by Martens et al. (2017) with the sample 
taken in South Africa and the research by Shin and Lee (2014), discomfort (DIS) had a negative effect on perceived ease of use. Oppositely, the results of Martens et al. (2017) research with the sample collected in Germany and another study by Khadka and Kohsuwan (2018) show that discomfort (DIS) has no negative effect on perceived ease of use. Based on the differences above, the researcher tried to re-test this construct by formulating the hypothesis as follows.

H3: Discomfort has a negative effect on perceived ease of use.

\section{Effect of Insecurity on Perceived Ease of Use}

Insecurity is one of the negative dimensions in TRI which is defined as a feeling of lack of trust in the ability of technology in its efforts to complete work. Based on the research conducted by Martens et al. (2017) with the sample taken in South Africa and the research by Shin and Lee (2014), insecurity (INS) has a negative effect on perceived ease of use and perceived benefits. On the other hand, the research results of Martens et al. (2017) with the sample taken in Germany and the research performed by Khadka and Kohsuwan (2018) show that insecurity (INS) has no negative effect on perceived ease of use. Based on the differences in the studies described earlier, the researcher tried to re-test this construct by formulating the hypothesis below.

H4: Insecurity has a negative effect on perceptions of ease of use.

\section{Effect of Perceived Ease of Use on Interest in Using E-Wallet}

According to Venkatesh and Davis (1996) and Liu et al. (2019), perceived ease of use refers to the degree to which the potential users expect the largest systems to be effortless. Perceived ease of use indicates an individual belief that using an information technology system will not be a hassle or require a lot of effort to use. Based on the research by Liu et al. (2019) and Sitinjak (2019), perceived ease of use has a significant effect on the intention to use digital payment. The different result is shown by the research of Humbani and Wiese (2019), Martens et al. (2017), and Shin and Lee (2014) which show that perceived ease of use has no significant effect on continuing intention to use digital payment. Based on the differences in the studies above mentioned, the researcher tried to re-test this construct by formulating the hypothesis as follows.

H5: Optimism and Innovativeness have positive effects, while Discomfort and Insecurity have negative effects on interest in using e-wallet with Perceived Ease of Use as the intervening variable.

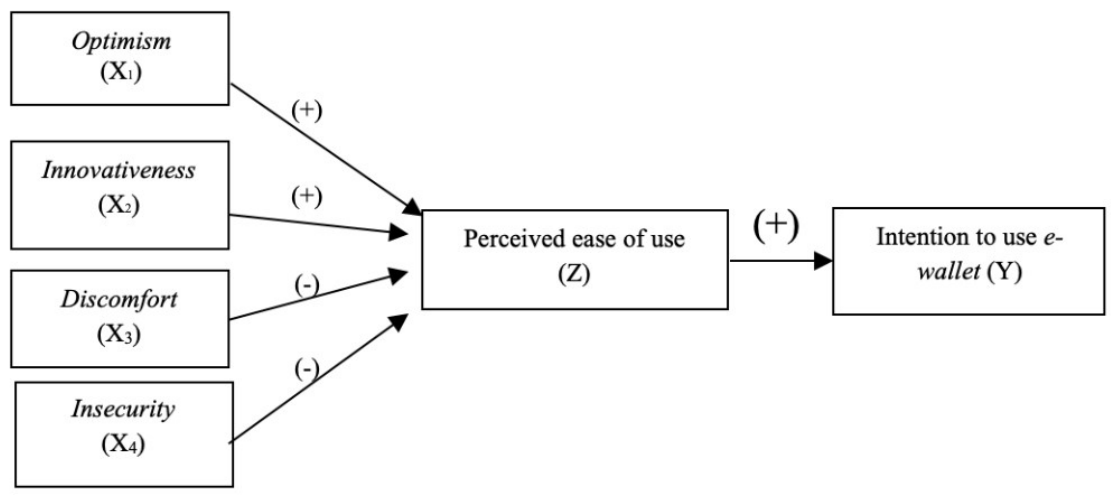

Figure 1. Research Framework

\section{Research Method}

The population of this study was all students currently studying in Yogyakarta Special Region Province and using digital payments. This study used purposive sampling. The specific criteria for the sample used were the students who were currently studying in Special Region of Yogyakarta and used digital payments, between 19-25 years old, and used e-wallet products. The minimum number of samples needed in this study was ten times the largest number of the measurement indicators in one of the variables (Hair et al., 2016). Thus, the calculation of the minimum number of samples needed is as follows:

$$
\begin{aligned}
\mathrm{N} & =\text { number of indicators } \times 10 \\
& =8 \times 10 \\
& =80 \text { samples }
\end{aligned}
$$

Based on the above calculation, the minimum number of samples in this study was 80 .

To convince that the respondents met the criteria, there were several preliminary questions involving: 1) Whether or not the respondents used e-wallet where $100 \%$ respondents confirmed that they were e-wallet user. 2) The length of period the respondents used e-wallet where $44,1 \%$ mentioned that they used it less than 2 years; $40,2 \%$ used it for 2 to 3 years, and 15,7\% already used e-wallet more than 3 years. 3) How frequent the 
respondents used e-wallet in a month in which the highest percentage of $49,6 \%$ of the respondents mentioned that they used e-wallet more than 5 times, $37,8 \%$ answered 2 to 5 times, and $12,6 \%$ was less than twice per month.

The data used in this study were primary data obtained directly from the student respondents who were currently studying in Special Region of Yogyakarta and using e-wallet products. In this study, the data collection method was a survey by distributing questionnaires. The data were measured using Likert Scale Model 1 to 6 . The use of even options in data collection will make respondents choose a clear attitude towards the statements given. Table 2 shows the distribution of respondents among universities in Yogyakarta.

Table 2. Indicators for each variable

\begin{tabular}{|c|c|c|}
\hline University & Number & Percentage \\
\hline UII & 71 & $56 \%$ \\
\hline UGM & 22 & $17,3 \%$ \\
\hline UMY & 6 & $4,7 \%$ \\
\hline UNY & 6 & $4,7 \%$ \\
\hline UPN & 9 & $7,1 \%$ \\
\hline UNIV. AMIKOM & 3 & $2,4 \%$ \\
\hline Other & 10 & $7,8 \%$ \\
\hline Total & 127 & 100,0 \\
\hline
\end{tabular}

Table 3 shows the number of indicators for each variable adopted in the questionnaire used and their references.

Table 3. Indicators for each variable

\begin{tabular}{|c|c|c|c|}
\hline Variable Name & $\begin{array}{l}\text { Variable } \\
\text { Type }\end{array}$ & $\begin{array}{l}\text { Number of } \\
\text { Indicators }\end{array}$ & References \\
\hline Optimism & Independent & 6 & $\begin{array}{l}\text { Shin and Lee (2014), Simiyu and Kohsuwa (2019), and Parasuraman and } \\
\text { Colby (2014) }\end{array}$ \\
\hline Innovativeness & Independent & 6 & $\begin{array}{l}\text { Shin and Lee (2014), Simiyu and Kohsuwa (2019), and Parasuraman and } \\
\text { Colby (2014) }\end{array}$ \\
\hline Discomfort & Independent & 7 & $\begin{array}{l}\text { Shin and Lee (2014), Simiyu and Kohsuwa (2019), and Parasuraman and } \\
\text { Colby (2014) }\end{array}$ \\
\hline Insecurity & Independent & 8 & $\begin{array}{l}\text { Shin and Lee (2014), Simiyu and Kohsuwa (2019), and Parasuraman and } \\
\text { Colby (2014) }\end{array}$ \\
\hline Perceived Ease of Use & Intervening & 4 & Liu et al. (2019), Sitinjak (2019), and Venkatesh and Davis (1996) \\
\hline Intention to use e-wallets & Dependent & 3 & Liu et al. (2019), Sitinjak (2019), and Venkatesh and Davis (1996) \\
\hline
\end{tabular}

The research model can be written in the following equation:

$Z=a+b_{1} X_{1}+b_{2} X_{2}-b_{3} X_{3}-b_{4} X_{4}+e$

$\mathrm{Y}=\mathrm{a}+\mathrm{b}_{5} \mathrm{Z}+\mathrm{e}$

where:

a : Constant

$b_{1}$ : Regression coefficient between optimism and perceived ease of use

$\mathrm{b}_{2}$ : Regression coefficient between innovativeness and perceived ease of use

$b_{3}$ : Coefficient of regression between discomfort and perceived ease of use

$b_{4}$ : Coefficient of regression between insecurity and perceived ease of use

$b_{5}:$ Regression coefficient between perceived ease of use and intention to use e-wallets

$\mathrm{X}_{1}$ : Optimism variable

$\mathrm{X}_{2}$ : Innovativeness variable

$\mathrm{X}_{3}$ : Discomfort variable

$\mathrm{X}_{4}$ : Insecurity variable

$Z$ : Perceived ease of use variable

$\mathrm{Y}$ : Intention to use e-wallets variable

The data analysis method used in this study was Partial Least Square (PLS) method. The stages of analysis using PLS method according to Hair et al. (2016) are: 1) Analysis of path diagrams to interpret PLS software output, 2) Analysis of measurement models (outer models) to evaluate the relationships between construct variables and indicators or manifest variables, 3) Structural analysis (inner model) to evaluate the estimated results of the path coefficient parameter and its level of significance. 


\section{Results and Discussion}

The data in this study were obtained directly from the student respondents who were currently studying in the Province of D.I. Yogyakarta and used e-wallet products. The number of questionnaires that were filled in by the respondents was 130 questionnaires. However, of the 130 questionnaires received, there were 3 questionnaires that did not meet the requirements, so the data that could be processed contained 127 questionnaires.

The majority of the respondents in this study was women. From the total 128 respondents, 81 respondents were female. Most of the respondents were UII students aged 19-21 years with the majority of monthly expenditures between IDR 1,000,000 - IDR 3,000,000 and had used e-wallets for less than 2 years. The frequency of using e-wallets was more than 5 times a month.

\section{Descriptive Analysis}

The descriptive analysis carried out in this study showed that the average (mean) value of each indicator in optimism and innovativeness variables had very high score which signified that the respondents felt optimistic, had innovative thinking, and had perception that e-wallet technology was easy to use. used. Then the average (mean) value of each indicator in discomfort and insecurity variables mostly showed that respondents agreed with the feeling of discomfort and insecurity when using e-wallet technology, but the users disagreed that e-wallets were difficult to use. The average (mean) value of each indicator in perceived ease of use variable demonstrated that the responses to the indicators in perceived ease of use and intention to use e-wallets has high scores, which means that the respondent felt the ease of using e-wallets and intended to use it.

\section{The outer model}

\section{Convergent Validity}

The first test showed the results of data testing where there were several low loading factors with the values below the required value of 0.5 . This shows that some indicators were considered less valid. Therefore, the invalid questionnaire items were dropped in the data processing so that the resulting loading factor values were as required. Hence, the results showed that all items matched each of the factors and had loading factor values $>$ 0.5 , as shown in the Table 3.

Table 3. Outer Loadings

\begin{tabular}{|c|c|c|c|}
\hline Variable & Item Code & Loading Factor & AVE \\
\hline \multirow{5}{*}{ Optimism (OP) } & OP1 & 0.641 & \multirow{5}{*}{0.540} \\
\hline & OP3 & 0.640 & \\
\hline & OP4 & 0.803 & \\
\hline & OP5 & 0.829 & \\
\hline & OP6 & 0.739 & \\
\hline \multirow{6}{*}{ Innovativeness (INN) } & INN1 & 0.670 & \multirow{6}{*}{0.518} \\
\hline & INN2 & 0.763 & \\
\hline & INN3 & 0.631 & \\
\hline & INN4 & 0.757 & \\
\hline & INN5 & 0.742 & \\
\hline & INN6 & 0.744 & \\
\hline \multirow{5}{*}{ Discomfort (DIS) } & DIS1 & 0.693 & \multirow{5}{*}{0.546} \\
\hline & DIS2 & 0.627 & \\
\hline & DIS3 & 0.710 & \\
\hline & DIS5 & 0.890 & \\
\hline & DIS7 & 0.750 & \\
\hline \multirow{6}{*}{ Insecurity (INS) } & INS1 & 0.724 & \multirow{6}{*}{0.589} \\
\hline & INS2 & 0.602 & \\
\hline & INS3 & 0.741 & \\
\hline & INS4 & 0.954 & \\
\hline & INS5 & 0.860 & \\
\hline & INS8 & 0.671 & \\
\hline \multirow{4}{*}{ Perceived Ease of Use (PEOU) } & PEOU1 & 0.811 & \multirow{4}{*}{0.766} \\
\hline & PEOU2 & 0.888 & \\
\hline & PEOU3 & 0.880 & \\
\hline & PEOU4 & 0.919 & \\
\hline \multirow{3}{*}{ Intention to use e-Wallet (BI) } & BI1 & 0.881 & \multirow{3}{*}{0.773} \\
\hline & BI2 & 0.904 & \\
\hline & BI3 & 0.852 & \\
\hline
\end{tabular}

Source: Research results, 2020. 
Table 3 shows that after dropping the invalid items, the loading factor and AVE values for all question items from all research variables had values above 0.5. It can be concluded that all question items from all research variables used in this study were valid or met the convergent validity test.

Discriminant Validity and Reliability Test

Table 4. Latent Variable Correlations and Reliability Test

\begin{tabular}{lcccccccccc}
\hline \multicolumn{1}{c}{ Construct } & DIS & \multirow{2}{*}{ INN } & \multirow{2}{*}{ INS } & \multirow{2}{*}{ BI } & \multirow{2}{*}{ OP } & PEOU & $\begin{array}{c}\text { Composite } \\
\text { Reliability }\end{array}$ & $\begin{array}{c}\text { Cronbach } \\
\text { Alpha }\end{array}$ & Criteria \\
\hline Optimism (OP) & $-0,160$ & 0.619 & 0.028 & 0.552 & 0.735 & & 0.853 & 0.784 & 0.7 & Reliable \\
Innovativeness (INN) & $-0,221$ & 0.720 & & & & & 0.865 & 0.813 & 0.7 & Reliable \\
Discomfort (DIS) & 0.739 & & & & & & 0.856 & 0.807 & 0.7 & Reliable \\
Insecurity (INS) & 0.484 & $-0,110$ & 0.768 & & & & 0.894 & 0.888 & 0.7 & Reliable \\
Perceived Ease of Use (PEOU) & -0.141 & 0.632 & 0.081 & 0.596 & 0.621 & 0.875 & 0.929 & 0.897 & 0.7 & Reliable \\
Intention to use e-Wallet (BI) & $-0,080$ & 0.509 & 0.120 & 0.879 & & & 0.911 & 0.853 & 0.7 & Reliable \\
\hline
\end{tabular}

Source: Research results, 2020.

Based on Table 4, it can be concluded that the values of AVE square root for all constructs were greater than the correlation values between constructs and other constructs, so all variables have high and valid discriminant validity.

It can also be seen that the composite reliability and Cronbach alpha values of each research variable all were $>0.7$. Thus, it can be concluded that all variables had a high level of reliability.

\section{The Inner Model}

\section{Goodness-fit Model}

Table 5. R- Square

\begin{tabular}{lc}
\hline \multicolumn{1}{c}{ Construct } & R Square \\
\hline Perceived ease of use & 0.502 \\
Intention to use e-wallets & 0.356 \\
\hline
\end{tabular}

Source: Research results, 2020.

Table 5 shows that the R-Square values of perceived ease of use and intention to use e-wallets were among 0,33 to 0,66 and qualified as moderate (Ghozali \& Latan, 2015).

\section{Hypothesis Testing and Discussion}

Hypothesis testing in the study was carried out by looking at the t-statistical value and p-value. The hypothesis is supported if the t-statistical value $>$ t-table $(1.6570)$ and the p-value $<0.05$. The results of hypothesis testing can be seen in the Table 6.

Table 6. Results of Path Coefficients

\begin{tabular}{cccccc}
\hline Hypothesis & Path & $\begin{array}{c}\text { Original } \\
\text { Sample }\end{array}$ & T-Statistics & P Value & \\
\hline H1 & OP $\rightarrow$ PEOU & 0.348 & 3,728 & 0,000 & Supported \\
H2 & INN $\rightarrow$ PEOU & 0.418 & 4,787 & 0,000 & Supported \\
H3 & DIS $\rightarrow$ PEOU & -0.065 & 0.848 & 0.397 & Not Supported \\
H4 & INS $\rightarrow$ PEOU & 0.149 & 1,431 & 0.153 & Not Supported \\
H5 & PEOU $\rightarrow$ BI & 0.596 & 10,187 & 0,000 & Supported \\
\hline
\end{tabular}

Source: Research Results, 2020.

\section{Hypothesis 1}

Based on the test results presented in Table 6, it can be concluded that optimism has a positive and significant effect on perceived ease of use, so hypothesis 1 which states that optimism has a positive effect on perceived ease of use is supported.

The results of this study indicate the conformity with the research of Shin and Lee (2014) which states that optimism has a significant and positive effect on perceived ease of use. This means that the higher the sense of optimism in an individual, the higher the perceived ease of use by the individual, but conversely if the feeling of optimism in the individual is low, the perceived ease of use by the individual is also low. 
Optimism is defined as a positive view on technology and the belief that technology provides increased control, flexibility and efficiency in one's life (Khadka \& Kohsuwan, 2018; Parasuraman, 2000). If it is associated with the results of descriptive statistical analysis on optimism variable, this variable in its each indicator had an average value close to and exceeding 5.16 interval, so it can be said that the in average the respondents agreed that e-wallet was easy to use. The users had a positive view that the existence of e-wallet technology could make life easier for them to carry out financial transactions efficiently. The ease to control and more flexibility in use also shaped the user's perception that e-wallet technology was easy to use.

\section{Hypothesis 2}

The second hypothesis in this study states that innovativeness has a positive effect on perceived ease of use. The test results summarized in Table 6 show that innovativeness has a positive and significant effect on perceived ease of use, so hypothesis 2 is supported.

The results in this study indicate the conformity with the previous research conducted by Martens et al. (2017), Khadka and Kohsuwan (2018), and Shin and Lee (2014) which states that innovativeness has a significant and positive effect on perceived ease of use. This means that the more innovative an individual thinking, the higher the perceived ease of use by the individual, but conversely, if the innovative thinking in the individual is low, the perceived ease of use by the individual is also low.

Innovativeness or innovative thinking is a tendency to become technology pioneers and thought leaders (Khadka \& Kohsuwan, 2018; Parasuraman, 2000). The point is that this innovative thinking can provide confidence to be motivated by the technology. If associated with the results of descriptive statistical analysis of innovativeness variable, this variable in its each indicator had an average value close to and exceeding 4.33 interval, so it can be said that in average the respondents agreed that e-wallets were easy to use. Innovativeness indicator refers to the degree to which a person is interested in experimenting with technology and becomes a pioneer in trying the latest technology-based products or services (Aisyah et al., 2014). Even though in their environment, the respondents were neither among the first users of the new technology when it was first launched nor those who were asked by other people for their opinions regarding the new technology, the respondents as users could find out and master the technology without the help of others. They did not face many problems in using technology and liked using the most advanced technology. This means that the users had a positive view that e-wallet technology was easy to use because when the users were interested in trying the latest technology products or services, the users could find out and master the technology without the help of others and did not face many problems in using it, so the technology of e-wallet was considered easy to use or to operate.

\section{Hypothesis 3}

The test results summarized in Table 6 show that hypothesis 3 which states that discomfort has a negative effect on perceived ease of use is not supported.

The results in this study indicate the conformity with the previous research conducted by Martens et al. (2017) and Khadka and Kohsuwan (2018) which stated that discomfort had no effect on perceived ease of use. Discomfort is a perceived lack of control over technology and a feeling of being overwhelmed by it (Martens et al., 2017; Parasuraman, 2000). Discomfort variable shows a feeling of lack of mastery and insecurity in using the latest technology which causes discomfort in using it. If it is related to the results of the descriptive statistical analysis of discomfort variable, most of its indicators had an average value close to and exceeding 3.50, which means that in average the respondents agreed that there were some aspects indicating the weakness of e-wallet technology that was considered to be uncomfortable to use.

The users realized that e-wallet technology had weaknesses that could make users feel less comfortable in using it. The factors from outside the individual, such as system errors or bugs in the application which cause the application cannot run properly can also make users feel uncomfortable. Based on the research by Khadka and Kohsuwan (2018), payment service providers need to understand and analyze every important part of the entire service and fix the parts that might create inconvenience when users use digital payment services.

Even though users feel inconvenient in using e-wallets, the current demands that require speed and convenience make people want to use e-wallets. The public feels helped by the ease of e-wallet access which makes it easier for people to make transactions flexibly and efficiently. This causes people to ignore the discomfort they feel and keep viewing e-wallets as easy to use that they still want to use e-wallets.

\section{Hypothesis 4}

The fourth hypothesis in this study states that insecurity has a negative effect on perceived ease of use. The test results summarized in Table 6 show that insecurity has no effect on perceived ease of use, so this hypothesis is not supported. 
The results in this study indicate the conformity with the previous research conducted by Martens et al. (2017) and Khadka and Kohsuwan (2018) which states that insecurity has no effect on perceived ease of use. Insecurity refers to a sense of distrust in technology-based transactions and doubts against the workability of the technology (Martens et al., 2017; Parasuraman, 2000). If associated with the results of descriptive statistical analysis of insecurity variable, most of its indicators on these variables had an average value close to and exceeding 4.33 interval, so it can be said that in average the respondents agreed that in using e-wallet technology there was a sense of fear or insecurity that using e-wallet application posed a security risk to its users.

The users were certainly aware of the risks of insecurity in using e-wallet applications. There have been several cases of e-wallets insecurity. According to Simiyu and Kohsuwa (2019), easy-to-use technology is also vulnerable to scammer, a person or group of people who commits fraud through cyberspace or the real world. The perpetrator tends to deceive the victim because of ignorance of information related to e-wallets. Therefore, it is important for the users to know the basic information, such as password that should not be shared with anyone, limit of balance that can be stored on e-wallet application, limit of the number of electronic money transactions, and so on.

In general, when the users feel insecure about the technology, the users tend not to try and find out more about the latest technology and will avoid using the technology, except when the user is in the state of necessity. However, back to the demands of current needs that require speed and convenience, users are still intended to use e-wallet applications. This is because the respondents as users feel helped by the existence of e-wallets that enables the users to make efficient and flexible transactions, so the users tend to ignore their perceived insecurity.

\section{Hypothesis 5}

The test results summarized in Table 6 show that optimism and innovativeness have positive effects and discomfort and insecurity have negative effects on intention to use e-wallets with perceived ease of use as the intervening variable. Thus, hypothesis 5 is supported. However, considering that the results on the third and fourth hypotheses are not significant, additional testing was conducted outside the research model. This was to ascertain the effects of intervening variable on the proposed research framework. The following are the results of the test on the direct relationship between discomfort (DIS) and insecurity (INS) variables and intention to use ewallets $(\mathrm{BI})$.

Table 7. Partial test results

\begin{tabular}{ccccc}
\hline Path & Original Sample & T Statistics & P Values & \\
\hline DIS $\rightarrow$ BI & -0.195 & 1,297 & 0.195 & Not Significant \\
INS $\rightarrow$ BI & 0.234 & 1,147 & 0.252 & Not Significant \\
\hline
\end{tabular}

With t-table value 1.6570 and $p$-value exceeding 0.05 , the partial test results above stated that discomfort (DIS) and insecurity (INS) variables did not significantly influence intention to use e-wallet (BI) variable. Thus, in hypothesis 5 , it can be concluded that the intervening variable, namely perceived of ease of use, is partially functional. In other words, for the optimism and innovativeness variables, the intervening variable could strengthen its influence on the intention to use e-wallets. However, for the discomfort and insecurity variables, the intervening variable had no effect which was shown by both tests, using the intervening variable and direct test (without the intervening variable, that had the same results, namely not significant.

Furthermore, for the optimism and innovativeness variables, the perceived ease of use variable strengthens their influences on the intention to use e-wallet because the perceived ease of use is the user's perception on the amount of effort required to use the system or technology (Liu et al., 2019; Venkatesh \& Davis, 1996). Perceived ease of use shows the belief that using an information technology system will not be a hassle and does not require a lot of effort when using it. This is consistent with the discussions about the research results of the variables of optimism and innovativeness above. If the users have a positive view that the existence of ewallet technology can make life easier for them to make financial transactions (optimism), and the users can find out and master the technology without the help of others and do not face many problems in using the technology (innovativeness), this will encourage the users' intention to use the technology.

\section{Conclusion}

Based on the data testing and analysis, the first hypothesis in this study is proven that optimism has a significant and positive effect on perceived ease of use. The second hypothesis in this study also proves that innovativeness or innovative thinking has a significant and positive effect on perceived ease of use. This means that optimistic attitude and innovative thinking in individuals affect the perception that e-wallets is easy to use because in using e-wallets, the users can learn and understand without the help of others and do not face many problems in using the e-wallets. 
Furthermore, testing the third hypothesis in this study proves that discomfort has no effect on perceived ease of use, and testing the fourth hypothesis in this study also proves that insecurity has no effect on perceived ease of use. This suggests that a sense of insecurity in an individual does not affect the user's perceived ease of use. Then, testing the fifth hypothesis in this study proves that the perceived ease of use strengthens the relationships between optimism and innovativeness on intention to use e-wallet, but it does not have significant effects on the discomfort and insecurity relationships with intention to use e-wallet.

Along with the popularity of e-wallet in Indonesia, this study might enrich the discussions on the literature about the use of TRAM as a model to evaluate this e-wallet technology. E-wallet product service providers are encouraged to increase the security and convenience of the system so that the users will feel safer and more comfortable in using e-wallets and can increase the users' intention to use e-wallets. Business owners are encouraged to collaborate with e-wallet product companies in order that people will become more technologically literate and able to implement a cashless system that is physically safer because they do not need to carry cash and at the same time enables them to have more accurate nominal. The public as the users of ewallet products are expected to further increase intention to use e-wallet payments but not to reduce their awareness of the security of e-wallet technology and learn how to act if something wrong happens that makes users feel uncomfortable or insecure.

In conducting the research, the researcher faced some difficulties which created some limitations which affected the research results. The first limitation is the data collection method using online questionnaire which required the respondents to fill out the questionnaires by themselves without any verbal direction. This method has a weakness. In this case is there were respondents who were not serious or honest and could not be controlled in the process of filling out the questionnaire. Moreover, the majority of the respondents were UII students.

In addition, in this study, the e-wallet application was considered less specific. This causes the results of this study that are general in nature based on the various e-wallet products used in Indonesia, especially in Yogyakarta. Consequently, this study only shows the results of the analysis on the object of research which is limited to the use of e-wallets in the city of Yogyakarta, so there may be differences in results and conclusion when the study is carried out with other objects, such as the use of e-wallets in Central Java, Jakarta, East Java, or other areas.

\section{References}

Aisyah, M. N., Nugroho, M. A., \& Sagoro, E. M. (2014). Pengaruh technology readiness terhadap penerimaan teknologi komputer pada UMKM di Yogyakarta. Jurnal Economia, 10(2), 105-119.

Bank Indonesia. (2020). Sistem Pembayaran \& Pengelolaan Uang Rupiah. Bank Indonesia.

Cermati.com. (2017). Plus dan Minus Cashless di Indonesia dan Upaya Perbaikan yang Perlu Ditingkatkan. Cermati.Com.

Chin, W. W. (1998). The partial least squares approach for structural equation modeling. In G. A. Marcoulides (Ed.), Modern Methods for Business Research (Issue January 1998). Lawrence Erlbaum Associates.

Davis, F. D., Bagozzi, R. P., \& Warshaw, P. R. (1989). User acceptance of computer technology: A comparison of two theoretical models. Management Science, 35(8), 982-1003.

Finansialku.com. (2017). Teknologi Finansial: Tengok Dulu Perkembangan Fintech Di Indonesia! Finansialku.Com.

Ghozali, I., \& Latan, H. (2015). Partial Least Squares: Konsep, Teknik dan Aplikasi Menggunakan Program SmartPLS 3.0(2nd ed.). Badan Penerbit Universitas Dipenogoro Semarang.

Hair, J. F., Hult, G. T. M., Ringle, C., \& Sarstedt, M. (2016). A Primer on Partial Least Squares Structural Equation Modeling (PLS-SEM). SAGE Publications Ltd.

Humbani, M., \& Wiese, M. (2019). An integrated framework for the adoption and continuance intention to use mobile payment apps. International Journal of Bank Marketing, 37(2), 646-664.

Khadka, R., \& Kohsuwan, P. (2018). Understanding consumers' mobile banking adoption in Germany: An integrated technology readiness and aceptance model (TRAM) perspective. Catalyst, 18, 56-67.

Lin, C.-H., Shih, H.-Y., Sher, P. J., \& Wang, Y.-L. (2005). Consumer adoption of e-service: integrating technology readiness with the technology acceptance model. A Unifying Discipline for Melting the Boundaries Technology Management, 483-488.

Liu, Y., Wang, M., Huang, D., Huang, Q., Yang, H., \& Li, Z. (2019). The impact of mobility, risk, and cost on the 
users' intention to adopt mobile payments. Information Systems and E-Business Management, 17, 319342.

Martens, M., Roll, O., \& Elliott, R. (2017). Testing the Technology Readiness and Acceptance Model for Mobile Payments Across Germany and South Africa. International Journal of Innovation and Technology Management, 14(6), 1-19.

Parasuraman, A. (2000). Technology readiness index (Tri): A multiple-item scale to measure readiness to embrace new technologies. Journal of Service Research, 2(4), 307-320.

Parasuraman, A., \& Colby, C. L. (2014). An Updated and Streamlined Technology Readiness Index: TRI 2.0. Journal of Service Research, 18(1), 59-74.

PRIMA. (2020). Indonesia Menuju Cashless Society. BNI PRIMA.

Shin, S., \& Lee, W. (2014). The effects of technology readiness and technology acceptance on NFC mobile payment services in Korea. Journal of Applied Business Research, 306), 1615-1626.

Simiyu, S. C., \& Kohsuwa, P. (2019). Understanding consumers' mobile banking adoption through the integrated technology readiness and acceptance model (TRAM) perspective: A comparative investigation. Human Behavior Development and Society, 20(1), 29-40.

Sitinjak, T. (2019). Pengaruh persepsi kebermanfaatan dan persepsi kemudahan penggunaan terhadap minat penggunaan layanan pembayaran digital Go-pay. Jurnal Manajemen, 8(2), 27-39.

Venkatesh, V., \& Davis, F. D. (1996). A model of the antecedents of perceived ease of use: Development and test. Decision Sciences, 27(3), 451-481. 